\title{
Effectiveness of Silver Nanoparticles against Root-Knot Nematode, Meloidogyne incognita Infecting Tomato under Greenhouse Conditions
}

\author{
Ahmed Hammad Nour El-Deen ${ }^{1,3}$ \& Bahig Ahmed El-Deeb ${ }^{2,3}$ \\ ${ }^{1}$ Agricultural Zoology Department, Mansoura University, Mansoura, Egypt \\ ${ }^{2}$ Botany and Microbiology Department, Sohag University, Sohag, Egypt \\ ${ }^{3}$ Biology Department, Taif University, Taif, Saudi Arabia \\ Correspondence: Ahmed Hammad Nour El-Deen, Biology Department, Taif University, Taif 21974, Saudi \\ Arabia. Tel: 966-55-311-7560. E-mail: ahnoureldeen2003@yahoo.com
}

Received: November 4, 2017

Accepted: December 4, 2017 Online Published: January 15, 2018

doi:10.5539/jas.v10n2p148

URL: https://doi.org/10.5539/jas.v10n2p148

\begin{abstract}
Root-knot nematode, Meloidogyne incognita is the most economically important plant parasitic nematode species that cause serious damage to most agricultural crops including tomato worldwide. Nematicides do not provide long-term suppression of root-knot nematodes, and environmental and human health concerns are resulting in increased restrictions on their use. A greenhouse experiment was conducted to evaluate the effect of silver nanoparticles (AgNPs) at concentrations of $0.25,0.5$ and $1 \mathrm{mM}$ as a potential nematicide on M. incognita infecting tomato. AgNP was biologically and chemically synthesized by a reaction of silver nitrate with ginger (Zingiber officinale) rhizomes aqueous extract and sodium borohydride, respectively. Results indicated that application of AgNPs improved plant growth and reduced nematode infection in comparison to silver nitrate and control treatments. The highest increment of fresh weight as well as the lowest numbers of galls and egg-masses was obtained when tomato plants was treated with AgNP produced by ginger extract at $1 \mathrm{mM}$.
\end{abstract}

Keywords: silver nanoparticles, Meloidogyne incognita, tomato, nematicide

\section{Introduction}

Plant parasitic nematodes caused significant damage to most agricultural crops reducing the yield and quality, causing loses valued at over $\$ 75$ billion per annum in the tropical and sub-tropics (Luc et al., 2005). Worldwide, crop loss attributed to these pests could be estimated by 20.6\% (Sasser \& Freckman, 1987). Root-knot nematodes (RKNs, Meloidogyne species) have broad host plant specificity and are responsible for > US $\$ 125$ billion annually in world-wide crop losses (Chitwood, 2003). M. arenaria, M. hapla, M. javanica and M. incognita are considered to be the most popular species that caused more than $90 \%$ of the estimated damages, they affected major both field and vegetable crops. The most damaging of all root-knot nematodes is the southern RKN, M. incognita, which infects almost all agricultural plants including tomato. Due to environmental restrictions on nematicidal use for controlling plant parasitic nematodes, biological control measures have gained increasing interest; however, there is still a need for alternative compounds for effective nematode control to be developed (Noling \& Becker, 1994).

The development of nanotechnologies is now being observed worldwide. Nanotechnology has a great impact on biological sciences and more and more nanomaterials are used in medicine, pharmacy and agriculture (Myczko, 2006). Silver nanoparticles (AgNPs) have emerged as an arch product from the field of nanotechnology. Over the last few years due to its good conductivity, chemical stability, catalytic and antibacterial activity silver has gained much of the interest. Production of silver nanoparticles can be achieved through different methods (Hardman, 2006). Chemical approaches are the most popular methods for the production. However, some chemical methods cannot avoid the use of toxic chemicals in the synthesis protocol (Ahmad et al., 2003). To overcome this problem, researchers are moving towards the use of clean, nontoxic, harmless and environmentally friendly biological methods or "green" chemistry such as use of plant extracts. There are several reports that claimed that plant extracts have been recorded to posses nematicidal and nematostatic properties (Nour El-Deen \& Darwish, 2011; Nour El-Deen et al., 2014; Khan et al., 2017; Singh et al., 2017). 
Biosynthetic of metal ( $\mathrm{Ag}, \mathrm{Au}, \mathrm{Cu}$ and $\mathrm{Cd}$ ) nano-formulation of plant extracts has received an increasing attention because of their potential application in pest control.

AgNP has shown evidence of being a potentially effective nematicide (Roh et al., 2009), and its toxicity is associated with induction of oxidative stress in the cells of targeted nematodes (Lim et al., 2012). Ag-nano particles of Urtica urens extracts concomitant with rugby were effective in the management of $M$. incognita, since it increased nematicidal activity 11-fold more than the least toxic extract against eggs (Nassar, 2016). The toxicity of three nanoparticles, silver, silicon oxide and titanium oxide, to the root-knot nematode, Meloidogyne incognita, was recorded in laboratory and pot experiments (Ardakani, 2013). Although most researchers have investigated the antifungal, antiviral and antibacterial activities of AgNPs, little attention has been given to nematicidal activities of such material. Therefore, the aim of this study was to evaluate the effectiveness of biological and chemical Ag-nano formulations against the root-knot nematode, $M$. incognita under greenhouse conditions.

\section{Materials and Methods}

\subsection{Plant Extract Preparation}

Ginger (Zingiber officinale) rhizomes were purchased from local market, Taif, KSA. Rhizomes were washed with distilled water to remove debris and soil. Plant rhizomes were cut into small pieces, and dried in a vacuum oven for $3 \mathrm{~h}$. A portion of $25 \mathrm{~g}$ was crushed in an electric blender with adding $200 \mathrm{ml}$ of Milli-Q water during crushing. The extract was stirred and incubated at room temperature for $6 \mathrm{~h}$, and filtered using a Whatman No 1 filter paper. The extract was stored at $4{ }^{\circ} \mathrm{C}$ until further use.

\subsection{Silver Nanoparticles Preparation}

For biological synthesis of silver nanoparticles, $90 \mathrm{ml}$ of $1 \mathrm{mM} \mathrm{AgNO}_{3}$ (in Milli-Q water) was taken in a sterile reaction bottle and $10 \mathrm{ml}$ of aqueous plant extract was added to it. The solution was mixed well and kept in a shaker incubator for overnight at $37{ }^{\circ} \mathrm{C}$. As a result, dark brown color solution was formed, indicating the formation of silver nanoparticles. AgNP was chemically synthesized according to (Fan et al., 2009) by adding 15 $\mathrm{ml}$ of $0.1 \mathrm{M} \mathrm{AgNO}_{3}$ to $970 \mathrm{ml}$ of $0.2 \%$ starch solution, and then $30 \mathrm{ml}$ of $0.1 \mathrm{M} \mathrm{NaBH} 4$ was added into the reaction solution. After stirring for $30 \mathrm{~min}$, a brown AgNP solution was appeared.

\subsection{Characterization of Silver Nanoparticles}

\subsubsection{Visual Observations and UV-Vis Spectra Analysis}

The biogenic and chemical synthesized of silver nanoparticles using plant rhizomes or sodium borohydride were characterized by UV-Vis spectroscopy (Perkin Elmer, Lambda 25) instrument scanning in the range of 200-900 $\mathrm{nm}$, at a resolution of $1 \mathrm{~nm}$ (Klaus-Jeorger et al., 2001; Ahmad et al., 2003). All Samples were prepared by centrifuging an aliquot of plant extract or chemical filtrate $(1.5 \mathrm{ml})$ at $10000 \mathrm{rpm}$ for $10 \mathrm{~min}$ and diluted 10 -fold for all experiments involving measurement of UV-Vis spectra. $\mathrm{AgNO}_{3}$ solution without addition of plant extract or sodium borohydride was used as a control throughout the experiment.

\subsubsection{Transmission Electron Microscopy (TEM)}

Samples of silver nanoparticles for transmission electron microscopy (TEM) analysis were prepared on carbon-coated copper TEM grids. Studies of size, morphology and composition of the nanoparticles were performed by means of transmission electron microscopy (TEM) operated at $120 \mathrm{kV}$ accelerating voltage (JTEM-1230, Japan, JEOL). Finally, the obtained images were processed using the software ImageJ. ImageJ developed at the National Institutes of Health (NIH), USA is a Java-based public domain image processing and analysis program (Rasband, 1997-2015).

\subsection{Bioassay}

Two-weeks-old tomato seedlings c.v. Super Strain B were transplanted into $15-\mathrm{cm}-\mathrm{d}$. plastic pots (one seedling/pot) filled with $2000 \mathrm{~g}$ of nematode-infested sandy loam soil (approximatly $2 \mathrm{~J}_{2} / \mathrm{g}$ of soil) collected from a pure culture of $M$. incognita that previously identified according to the characteristics of its perineal pattern (Taylor \& Sasser, 1978), maintained and propagated on eggplant. Seedlings of tomato were allowed to grow for another 15 days, then twenty four pots were treated with $15 \mathrm{ml}$ of AgNPs solutions at $0.25,0.50$ and $1.0 \mathrm{mM}$ on the soil surface. Twelve pots were recieved silver nitrate $\left(\mathrm{AgNO}_{3}\right)$ as a positive control, whereas, four untreated seedlings were left to serve as a negative control. All plastic pots were randomly arranged on a greenhouse bench at $25 \pm 2{ }^{\circ} \mathrm{C}$ and watered regularly as needed. The seedlings were uprooted 45 days later. Data dealing with length of shoot and root, and fresh weights of shoot and root were measured. The total number of galls and egg-masses per root system were recorded and root galling (RGI) and egg-mass (EI) indices were recorded based on a scale of 
$1-9$ where $1=$ no gall or egg-mass, $2=1-5,3=6-10,4=11-20,5=21-30,6=31-50,7=51-70,8=71-100$ and 9 $\geq 100$ galls or egg-masses/plant (Sharma et al., 1994). The experiment had four replicates and was repeated once.

\subsection{Statistical Analysis}

Statistically, the obtained data were subjected to analysis of variance (ANOVA) (K. A. Gomez \& A. A. Gomez, 1984) followed by Duncan's multiple range to compare means (Duncan, 1955).

\section{Results}

\subsection{Characterization of Silver Nanoparticles}

In this work, biofabricated of AgNPs by plant rhizomes extract as well as chemical one was described. Visual observation of the reaction of plant extract or sodium borohydride with silver nitrate at room temperature showed a color change from colorless to yellowish or dark brown whereas no color change could be demonstrated in $\mathrm{AgNO}_{3}$ alone (Figure 1). UV-Vis spectrum of the biosynthesis or chemical AgNPs is shown in the Figures 2 and 3, respectively. For biosynthesized AgNPs, Surface Plasmon peak observed at $450 \mathrm{~nm}$, whereas, a peak at $430 \mathrm{~nm}$ corresponds to the characteristic wavelength of AgNPs synthesized by chemical method.

\subsection{TEM Analysis}

Figure 4 showed the representative TEM image, with a size distribution on its right side. The TEM images of AgNPs and their size distribution produced either by biological or chemical method showed that the particles were spherical, and monodispersed with average diameter of 5-50 nm.

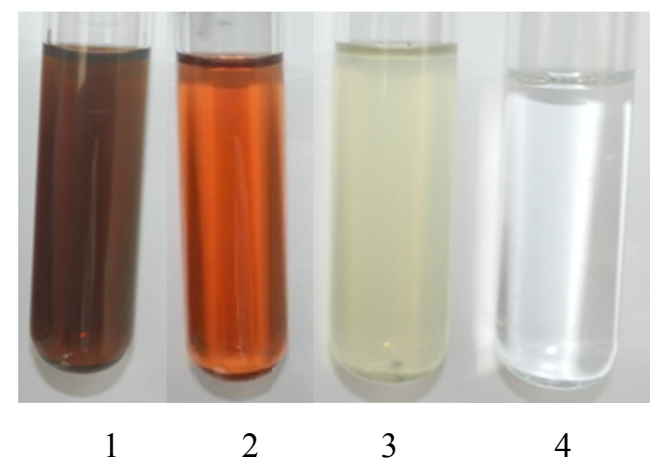

Figure 1. Digital photograph of synthesized silver nanoparticles by incubated of plant rhizome extract or sodium borohydride with $\mathrm{AgNO}_{3}$ solution for $24 \mathrm{~h}$ at $30^{\circ} \mathrm{C}$

Note. (1) biosynthesized AgNPs, (2) chemical AgNPs, (3) plant extract alone, and (4) $\mathrm{AgNO}_{3}$ alone.

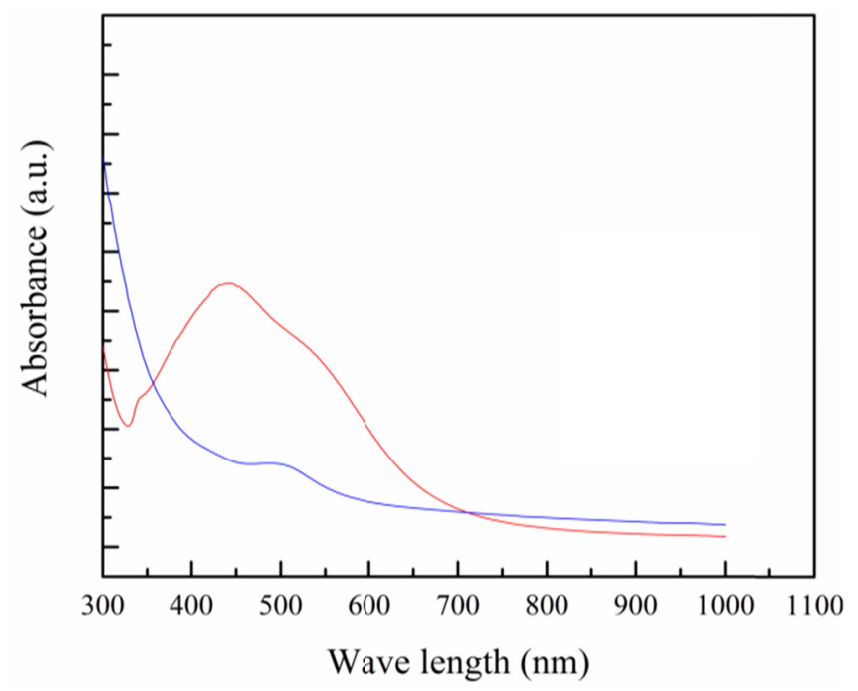

Figure 2. UV-Vis absorption spectrum of silver nanoparticles (AgNPs) synthesized using ginger extract 


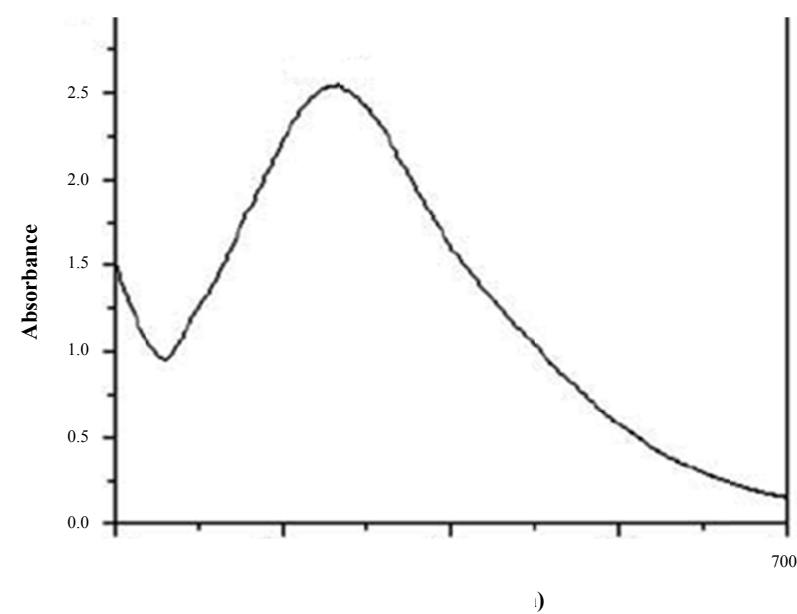

Figure 3. UV-Vis absorption spectrum of silver nanoparticles (AgNPs) synthesized using sodium borohydride

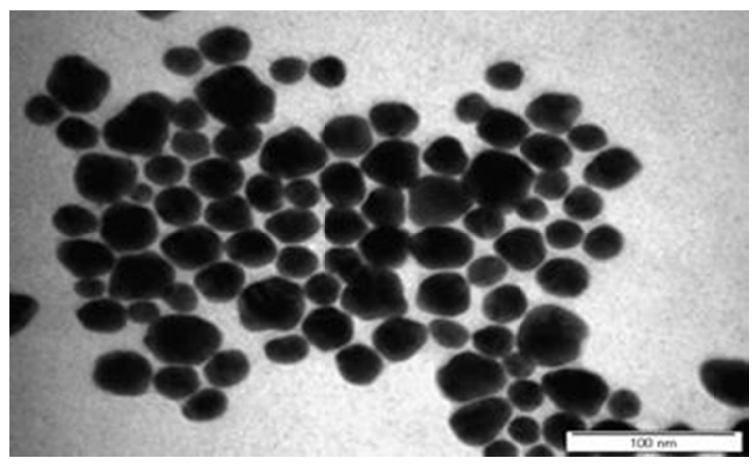

(A)

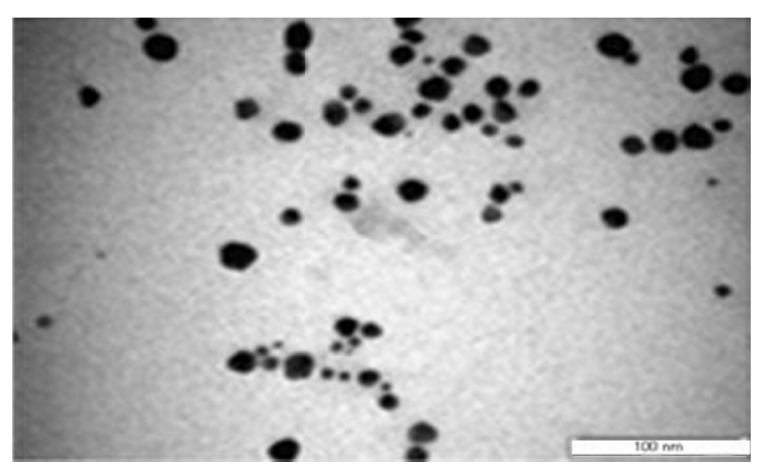

(C)

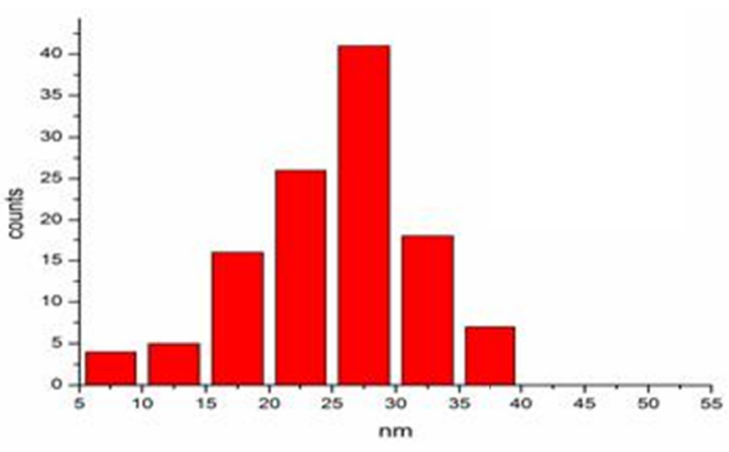

(B)

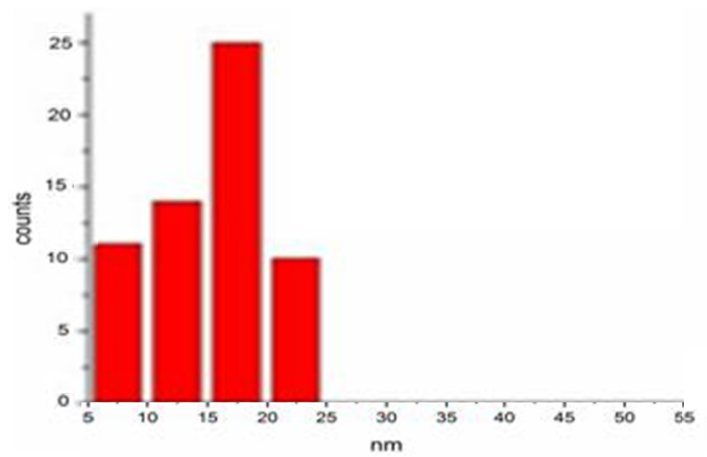

(D)

Figure 4. TEM images and particle size distributions of silver nanoparticles (AgNPs)

Note. AgNPs synthesized using plant extract (A \& B) and sodium borohydride (C \& D).

\subsection{Bioassay}

Data in the Table 1 represent the impact of biological and chemical synthesized AgNPs on the growth of tomato infected with $M$. incognita in comparison to $\mathrm{AgNO}_{3}$. Results indicated that all treatments caused remarkable improvement in tomato growth in terms of shoot and root length and fresh weight of shoot and root with various degrees as compared to control. Among all tested materials, chemical AgNP at $0.50 \mathrm{mM}$ significantly gave the highest increment in shoot and root lengths with values of 93 and $18 \mathrm{~cm}$, respectively. However, nanoparticles of Ag-ginger at high concentration did not significantly influence $(P \leq 0.05)$ the growth of tomato cv. Super Strain $\mathrm{B}$, determined by root length (Table 1). Fresh weights of tomato plants grown in untreated soil were significantly 
less than those grown in AgNP-treated soil. The weight of tomato plants grown in untreated soil was $16.3 \mathrm{~g}$, whereas those from soils treated with nanoparticles of Ag-ginger at 1.0, 0.50 and $0.25 \mathrm{mM}$ were $55.4,52$ and $48.2 \mathrm{~g}$, respectively. Likewise, moderate increment was obtained by the application of $\mathrm{AgNO}_{3}$ at 0.25 and 0.50 $\mathrm{mM}$ (37.5 and $33.6 \mathrm{~g}$ ), whereas, among all treatments, $\mathrm{AgNO}_{3}$ at higher concentration gave the least value of fresh weight that averaged $20.9 \mathrm{~g}$.

Data in the Table 2 reveal number of root galls, root gall index (RGI), number of egg-masses and egg-mass index (EI) of $M$. incognita infecting tomato as influenced by AgNPs those either chemically or biologically prepared. Significant results were noticed between all tested materials and nematode alone (control) with the indices of root galls and egg-masses number, since their values were ranged between 1.3 to 6 vs 7 for root galls and 1 to 4 vs 5 for egg-masses, respectively. The incidence of $M$. incognita infection of tomato plants was not affected by any of tested compounds, but the root galling was significantly reduced $(P \leq 0.05)$ by all treatments when compared with the non-treated one (Table 2).

Roots of tomato plants grown in Ag-ginger nanoparticles treated soil had very few or no galls, while control plants had heavily galled roots (Figure 5). The number of nematode egg-masses per plant was also significantly reduced by AgNPs treatments: in particular, no egg-masses were formed on tomato roots grown in soil amended with biological AgNPs at all concentrations tested.

Table 1. Effect of chemical and biological AgNPs on the growth of tomato seedlings infected with M. incognita under greenhouse conditions

\begin{tabular}{|c|c|c|c|c|c|c|}
\hline \multirow{3}{*}{ Treatments } & \multirow{3}{*}{ Conc. (mM) } & \multicolumn{5}{|c|}{ * Plant growth response } \\
\hline & & \multicolumn{2}{|c|}{ Length $(\mathrm{cm})$} & \multicolumn{2}{|c|}{ Fresh weight (g) } & \multirow{2}{*}{$\begin{array}{l}\text { Fresh wt. of the } \\
\text { whole plant }(\mathrm{g})\end{array}$} \\
\hline & & Shoot & Root & Shoot & Root & \\
\hline \multirow[t]{3}{*}{ Biological AgNP } & 0.25 & $86.3 \mathrm{~b}$ & $16 \mathrm{ab}$ & $45.3 \mathrm{~b}$ & $2.9 \mathrm{~cd}$ & $48.2 \mathrm{c}$ \\
\hline & 0.50 & $75.7 \mathrm{~cd}$ & $13 \mathrm{c}$ & $46.7 \mathrm{~b}$ & $5.3 \mathrm{a}$ & $52 \mathrm{~b}$ \\
\hline & 1.0 & $52 \mathrm{f}$ & $13 \mathrm{c}$ & $50.8 \mathrm{a}$ & $4.6 \mathrm{a}$ & $55.4 \mathrm{a}$ \\
\hline \multirow[t]{3}{*}{ Chemical AgNP } & 0.25 & $79.3 \mathrm{c}$ & $16 \mathrm{ab}$ & $37.3 \mathrm{c}$ & $3.8 \mathrm{~b}$ & $41.1 \mathrm{~d}$ \\
\hline & 0.50 & $93 \mathrm{a}$ & $18 \mathrm{a}$ & $34.6 \mathrm{c}$ & $3.3 \mathrm{bc}$ & $37.9 \mathrm{de}$ \\
\hline & 1.0 & $75 \mathrm{~d}$ & $16 \mathrm{ab}$ & $21.3 \mathrm{e}$ & $2.1 \mathrm{ef}$ & $23.4 \mathrm{~g}$ \\
\hline \multirow[t]{3}{*}{$\mathrm{AgNO}_{3}$} & 0.25 & $63 \mathrm{e}$ & $14 \mathrm{bc}$ & $35.3 \mathrm{c}$ & $2.2 \mathrm{ef}$ & $37.5 \mathrm{e}$ \\
\hline & 0.50 & $65 \mathrm{e}$ & $16 \mathrm{ab}$ & $31 \mathrm{~d}$ & $2.6 \mathrm{de}$ & $33.6 \mathrm{f}$ \\
\hline & 1.0 & $50 \mathrm{f}$ & $16 \mathrm{ab}$ & $19.3 \mathrm{e}$ & $1.6 \mathrm{fg}$ & $20.9 \mathrm{~g}$ \\
\hline Control (Check) & & $35 \mathrm{~g}$ & $12 \mathrm{c}$ & $15 \mathrm{f}$ & $1.3 \mathrm{~g}$ & $16.3 \mathrm{~h}$ \\
\hline LSD at 0.05 & & 4.2 & 2.6 & 2.9 & 0.7 & 3.2 \\
\hline
\end{tabular}

Note. Each value represents the mean of four replicates. Within each concentration, values with the same letter do not differ significantly according to $\operatorname{LSD}(P \leq 0.05)$.

Table 2. Effect of soil treatment with AgNPs on galls and egg-masses of tomato (index of 0 to 9) caused by $M$. incognita under greenhouse conditions

\begin{tabular}{|c|c|c|c|c|c|}
\hline Treatments & Conc. (mM) & No. of Galls & RGI & No. of Egg-masses & EI \\
\hline \multirow[t]{3}{*}{ Biological AgNP } & 0.25 & $4.7 \mathrm{~cd}$ & $2 \mathrm{ef}$ & $0 \mathrm{f}$ & $1 \mathrm{~d}$ \\
\hline & 0.50 & $2 d$ & $2 \mathrm{ef}$ & $0 \mathrm{f}$ & $1 \mathrm{~d}$ \\
\hline & 1.0 & $1.3 \mathrm{~d}$ & $1.3 \mathrm{f}$ & $0 \mathrm{f}$ & $1 \mathrm{~d}$ \\
\hline \multirow[t]{3}{*}{ Chemical AgNP } & 0.25 & $6 \mathrm{~cd}$ & $2.7 \mathrm{de}$ & $1 \mathrm{ef}$ & $1.7 \mathrm{~cd}$ \\
\hline & 0.50 & $10.3 \mathrm{c}$ & $3.3 \mathrm{~d}$ & $3.7 \mathrm{de}$ & $2 \mathrm{c}$ \\
\hline & 1.0 & $20.7 \mathrm{~b}$ & $4.3 \mathrm{c}$ & $5.3 \mathrm{~d}$ & $2.3 \mathrm{c}$ \\
\hline \multirow[t]{3}{*}{$\mathrm{AgNO}_{3}$} & 0.25 & $25 \mathrm{~b}$ & $5 \mathrm{c}$ & $12 \mathrm{c}$ & $4 \mathrm{~b}$ \\
\hline & 0.50 & $28 \mathrm{~b}$ & $5 \mathrm{c}$ & $14.7 \mathrm{bc}$ & $4 \mathrm{~b}$ \\
\hline & 1.0 & $48 \mathrm{a}$ & $6 \mathrm{~b}$ & $16 \mathrm{~b}$ & $4 \mathrm{~b}$ \\
\hline Control (Check) & & $55 \mathrm{a}$ & $7 \mathrm{a}$ & $24 \mathrm{a}$ & $5 a$ \\
\hline LSD at 0.05 & & 8.01 & 0.85 & 2.9 & 0.72 \\
\hline
\end{tabular}

Note. Each value represents the mean of four replicates. Within each concentration, values with the same letter do not differ significantly according to $\operatorname{LSD}(P \leq 0.05)$. 

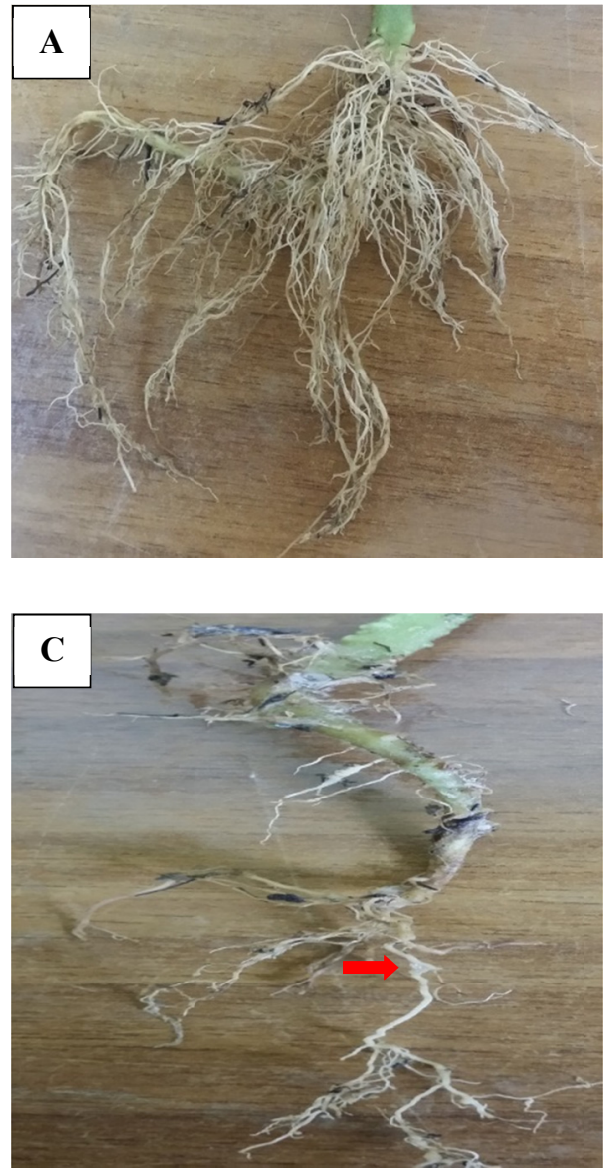
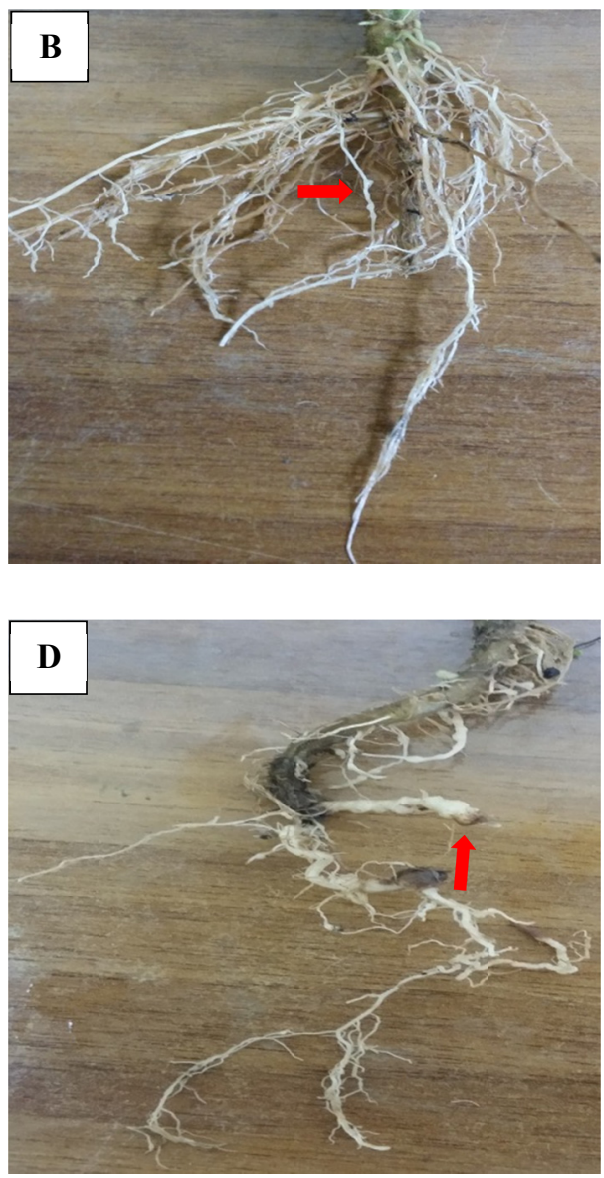

Figure 5. Roots of tomato plants grown in nematode-infested soil treated or untreated

Note. (A) Ag-ginger NP, (B) Chemical AgNP, (C) $\mathrm{AgNO}_{3}$ at a concentration of $1.0 \mathrm{mM}$, and (D) untreated soil (control). Arrow indicates to root galls.

\section{Discussion}

Apparently, the presence of spherical, monodispersed and small particles in TEM image is in accordance with the UV-Vis spectral study (Ahmad et al., 2003). It is well known that silver nanoparticles exhibit yellowish brown color in aqueous solution due to excitation of Surface Plasmon vibrations in silver nanoparticles (Jain et al., 2009).

In agreement with previous reports, the absorption peak at $455 \mathrm{~nm}$ is probably due to the excitation of longitudinal plasmon vibrations and formation of quasi-linear superstructures of nanoparticles (Mukherjee et al., 2001). Herein, application of nanoparticles those chemically or biologically prepared against $M$. incognita infecting tomato seedlings c.v. Super Strain B under greenhouse conditions significantly suppressed nematode population in return enhancement the plant growth parameters.

Data also revealed that Ag-ginger-NP significantly showed the highest increment in plant growth parameters in terms of shoot and root weights followed by chemical $\mathrm{AgNP}$ then $\mathrm{AgNO}_{3}$ for the same previous growth characters. Moreover, the greater and significant increase percentages in shoot and root lengths were recorded by the application of chemical AgNPs. The present findings agreed with that of Nassar (2016) in respect to nematicidal activity of Ag-nano particles of Urtica urens extracts concomitant with rugby against $M$. incognita in-vitro and silver, silicon oxide and titanium oxide nanoparticles to the root-knot nematode, $M$. incognita in laboratory and pot experiments (Ardakani, 2013). It is worth to note that although Ag-nano of ginger extract showed the highest reduction of nematode gall formation and egg-mass production, conversely it gave shorter roots in comparing to other treatments. A positive correlation was observed between root galling and chemical AgNP concentrations, since increasing concentration increased RGI, whereas, negative correlation was noticed regarding biological AgNP concentration. Our findings are in line with several reports that claimed that toxicity 
of sublethal doses of AgNP to nematodes can result in reproduction inhibition [with 0.05 to $0.5 \mathrm{mg} / \mathrm{ml}$ of $\mathrm{AgNP}$ for $72 \mathrm{~h}$ (Roh et al., 2009; Lim et al., 2012)] or growth inhibition [with 5 to $50 \mathrm{mg} / \mathrm{ml}$ of AgNP for 1 to $3 \mathrm{~d}$ (Meyer et al., 2010)]. This suggests the AgNP effect may be subtle and chronic at low concentrations applied in the field. Nematicidal effect of AgNP against root-knot nematodes likely applies to other genera of plant-parasitic nematodes and also to plant-pathogenic fungi, because its mode of action is not specific but associated with disrupting multiple cellular mechanisms including membrane permeability, ATP synthesis, and response to oxidative stress in both eukaryotic (Roh et al., 2009; Ahamed et al., 2010; Lim et al., 2012) and prokaryotic cells (Sondi \& Salopek-Sondi, 2004; Morones et al., 2005; Lok et al., 2006; Choi \& Hu, 2008). Results obtained from the present study clearly suggested that Ag-nano of ginger extract showed great potential in the inhibition of $M$. incognita development and improvement of tomato growth. On the other hand, $\mathrm{AgNO}_{3}$ application did not act as strong nematicide on nematodes, since it was found to be the least effective to enhance plant growth parameters as well as nematode development. These findings could be important from the point of view of using novel ecofriendly method to control the root-knot nematode without the use of chemical pesticides under greenhouse condition.

\section{Conclusion}

Conclusively, utilization of such technique in root-knot nematode control could gain new trend, safe and effective nematode management program. Therefore, further studies are needed to prepare and characterize biofabricated nanoparticle that are nematotoxic and possessing complex modes of action before recommend it for field application and IPM program against plant parasitic nematodes.

\section{References}

Ahamed, M., Posgai, R., Gorey, T. J., Nielsen, M., Hussain, S. M., \& Rowe, J. J. (2010). Silver nanoparticles induced heat shock protein 70, oxidative stress and apoptosis in Drosophila melanogaster. Toxicology and Applied Pharmacology, 242, 263-269. https://doi.org/10.1016/j.taap.2009.10.016

Ahmad, A., Mukherjee, P., Senapati, S., Mandal, D., Khan, M., Kumar, I. R., \& Sastry, M. (2003). Extracellular biosynthesis of silver nanoparticles using the fungus Fusarium oxysporum. Colloids Surfaces B: Biointerfaces, 27, 313-318. https://doi.org/10.1016/S0927-7765(02)00174-1

Ardakani, A. S. (2013). Toxicity of silver, titanium and silicon nanoparticles on the root-knot nematode, Meloidogyne incognita, and growth parameters of tomato. Nematology, 15(6), 671-677. https://doi.org/ 10.1163/15685411-00002710

Chitwood, D. J. (2003). Research on plant-parasitic nematode biology conducted by the United States Department of Agriculture-Agricultural Research Service. Pest Manag. Sci., 59, 748-753. https://doi.org/ $10.1002 /$ ps.684

Choi, O., \& Hu, Z. (2008). Size dependent and reactive oxygen species related nanosilver toxicity to nitrifying bacteria. Environmental Science and Technology, 42, 4583-4588. https://doi.org/10.1021/es703238h

Duncan, D. B. (1955). Multiple range and multiple, F-test. Biometrics, 11, 1-42. https://doi.org/10.2307/3001478

Fan, Y., Liu, Z., Wang, L., \& Zhan, J. (2009). Synthesis of starchstabilized Ag nanoparticles and $\mathrm{Hg}^{2+}$ recognition in aqueous media. Nanoscale Research Letters, 4, 1230-1235. https://doi.org/10.1007/ s11671-009-9387-6

Gomez, K. A., \& Gomez, A. A. (1984). Statistical procedures for agriculture research (2nd ed.). June Wiley \& Sons. Inc. New York. USA.

Hardman, R. (2006). Toxicologic review of quantum dots: Toxicity depends on physicochemical and environmental factors. Environ Health. Perspect., 114, 165-172. https://doi.org/10.1289/ehp.8284

Jain, D., Kumar, D. H., Kachhwaha, S., \& Kothari, S. L. (2009). Synthesis of plant-mediated silver nanoparticles using papaya fruit extract and evaluation of their anti microbial activities. Digest Journal of Nanomaterials and Biostructures, 4, 723-727.

Khan, A., Mohd, A., Moh, T., Bushra, R., Kavita, P., \& Mansoor, A. S. (2017). Phytochemical investigation, nematostatic and nematicidal potential of weeds extract against the root-knot nematode. Meloidogyne incognita in vitro. Asian Journal of Biological Sciences, 10, 38-46.

Klaus-Joerger, T., Joerger, R., Olsson, E., \& Granqvist, C. G. (2001). Bacteria as workers in the living factory: Metal-accumulating bacteria and their potential for materials science. Trends in Biotechnology, 19, 15-20. https://doi.org/10.1016/S0167-7799(00)01514-6 
Lim, D., Roh, J. Y., Eom, H. J., Hyun, J. W., \& Choi, J. (2012). Oxidative stress-related PMK-1 P38 MAPK activation as a mechanism for toxicity of silver nanoparticles to reproduction in the nematode Caenorhabditis elegans. Environmental Toxicology and Chemistry, 31, 585-592. https://doi.org/10.1002/ etc. 1706

Lok, C. N., Ho, C. M., Chen, R., He, Q. Y., Yu, W. Y., Sun, H., ... Che, C. M. (2006). Proteomic analysis of the mode of antibacterial action of silver nanoparticles. Journal of Proteome Research, 5, 916-924. https://doi.org/10.1021/pr0504079

Luc, M., Sikora, R. A., \& Bridge, J. (2005). Plant parasitic nematodes in subtropical and tropical agriculture (p. 871). CAB International, Wallingford, UK. https://doi.org/10.1079/9780851997278.0000

Meyer, J. N., Lord, C. A., Yang, X. Y., Turner, E. A., Badireddy, A. R., Marinakos, S. M., ... Auffan, M. (2010) Intracellular uptake and associated toxicity of silver nanoparticles in Caenorhabditis elegans. Aquat. Toxicol., 100, 140-150. https://doi.org/10.1016/j.aquatox.2010.07.016

Morones, J. R., Elechiguerra, J. L., Camacho, A., Holt, K., Kouri, J. B., Ramirez, J. T., \& Yacaman, M. J. (2005) The bactericidal effect of silver nanoparticles. Nanotechnology, 16, 2346-2353. https://doi.org/10.1088/ 0957-4484/16/10/059

Mukherjee, P. A., Ahmad, D., Mandal, S., Senapati, S., Sainkar, S. R., Khan, M. I., ... Sastry, M. (2001). Fungus-mediated synthesis of silver nanoparticles and their immobilization in the mycelial matrix: A novel biological approach to nanoparticle synthesis. Nano Lett., 1, 515-519. https://doi.org/10.1021/n10155274

Myczko, A. (2006). Zastosowanie nanotechnologii w praktyce rolniczej. Inz. Rol., 2, 45-50.

Nassar, A. M. (2016). Effectiveness of silver nano-particles of extracts of Urtica urens (Urticaceae) against root-knot nematode Meloidogyne incognita. Asian J. Nematol., 5(1), 14-19. https://doi.org/10.3923/ ajn.2016.14.19

Noling, J. W., \& Becker, J. O. (1994). The challenge of research and extension to define and implement alternatives to methyl bromide. J. Nematol., 26, 573-586.

Nour El-Deen, A. H., \& Darwish, H. Y. (2011). Nematicidal activity of certain Egyptian weeds and bald cypress callus extracts against Meloidogyne incognita infecting eggplant under greenhouse conditions. Egypt. J. Agronematol., 10 (2), 242-254.

Nour El-Deen, A. H., Cseh, E., \& Darwesh, H. Y. (2014). Evaluation of certain Hungarian plant extracts for their nematicidal properties against root-knot nematode, Meloidogyne incognita in-vitro. International Journal of Advanced Research, 2(8), 443-448.

Rasband, W. S. (1997-2015). ImageJ. U.S. National Institutes of Health, Bethesda, Maryland, USA. Retrieved from http://imagej.nih.gov/ij

Roh, J. Y., Sim, S. J., Yi, J., Park, K., Chung, K. H., \& Ryu, D. Y. (2009). Ecotoxicity of silver nanoparticles on the soil nematode Caenorhabditis elegans using functional ecotoxicogenomics. Environ Sci Technol., 43(10), 3933-3940. https://doi.org/10.1021/es803477u

Sasser, J. N., \& Freckman, D. W. (1987). A world prospective on nematology: The role of the society. In J. A. Veech \& D. W. Dickson (Eds.), Vistas on Nematology (pp. 7-14). Society of Nematologists, Hyattsville, MD.

Sharma, S. B., Sikora, R. A., Greco, N., Di Vito, M., \& Caubel, G. (1994). Screening techniques and sources of resistance to nematodes in cool season food legumes. Euphytica, 73, 59-66. https://doi.org/10.1007/ BF00027182

Singh, N. G., Anil, K., Sewak, R., \& Vinod, K. (2017). Evaluation of nematicidal activity of ethanolic extracts of medicinal plants to Meloidogyne incognita (Kofoid and White) Chitwood under lab conditions. Int. J. Pure App. Biosci., 5(1), 827-831.

Sondi, I., \& Salopek-Sondi, B. (2004). Silver nanoparticles as antimicrobial agent: A case study on E. coli as a model for Gram-negative bacteria. Journal of Colloid Interface Science, 275, 177-182. https://doi.org/10.1016/j.jcis.2004.02.012

Taylor, A. L., \& Sasser, J. N. (1978). Biology, identification and control of root-knot nematodes (Meloidogyne species) (p. 111). Coop. Publ, Dep. Plant Pathol., North Carolina State Univ., and U.S. Agency Int. Dev., Raleigh, NC. 


\section{Copyrights}

Copyright for this article is retained by the author(s), with first publication rights granted to the journal.

This is an open-access article distributed under the terms and conditions of the Creative Commons Attribution license (http://creativecommons.org/licenses/by/4.0/). 